\title{
Media Massa dan Politik Islam Pasca Reformasi 1998 (Studi Historis Komparatif dan Ekonomi Politik di Sumatera Utara)
}

\author{
Nirwansyah Putra \\ Universitas Muhammadiyah Sumatera Utara \\ e-mail: nirwansyahputra@umsu.ac.id
}

\begin{abstract}
The 1998 Reformation Movement and the No. 40/1999 Law on The Press has been widely studied. But not with the relation of mass media and Islamic politics. Questioning how the definition and meaning of Islamic politics in the media, the effects of media policy and the dynamics of Islamic politics, are serious questions that need to be developed and studied in general and specifically. Including, studying the trichotomic relationship between the State-Islam-Media. Related to, North Sumatra is already known as an area with high media intensity. This study uses a descriptive qualitative model which using historical-comparative and political-economic approach in analysis and qualitative interpretation. This paper describes the complex relations between the mass media and the dynamics of Islamic politics in the pre and post 1998 Reformation period.
\end{abstract}

Keyword : Press Freedom, Media Industrialization-Capitalization, Islamic Politics

\begin{abstract}
Abstrak
Gerakan Reformasi 1998 dan Undang-undang No. 40 Tahun 1999 tentang Pers telah banyak dikaji. Namun tidak dengan relasi media massa dan politik Islam. Mempertanyakan bagaimana definisi dan pemaknaan politik Islam di kalangan media, dampak-dampak kebijakan media serta dinamika politik Islam, adalah pertanyaan serius yang perlu dikembangkan dan dikajis secara umum maupun spesifik. Termasuk, memelajari hubungan trikotomis antara Negara-Islam-Media. Dalam kaitan itu, Sumatera Utara sudah dikenal sebagai daerah dengan intensitas media yang tinggi. Kajian ini memakai model studi kualitatif deskriptif dengan menggunakan pendekatan historis-komparatif dan ekonomi-politik dalam analisis dan interpretasi kualitatif. Tulisan ini menggambarkan relasi yang cukup kompleks antara media massa dan dinamika Politik Islam dalam periode waktu pra dan pasca Reformasi 1998.
\end{abstract}

Kata Kunci: Kebebasan Pers, Industralisasi-Kapitalisasi Media, Politik Islam 
Latar Belakang Masalah

Dalam konsep besar bernama

"Politik Islam" (sebagian memakai istilah Islam Politik), Indonesia adalah sebuah negara yang punya riwayat cukup dalam dan lama dengan pergulatan politik Islam. Dia mempunyai kekuatan potensial, baik dari komposisi penduduk yang menempatkan Indonesia sebagai negara dengan jumlah umat Islam terbesar di dunia, hingga pada adanya beberapa ramalan mengenai revivalisme Islam di dunia yang di antaranya diasumsikan bakal terjadi di Indonesia. Dengan demikian, politik Islam tidak hanya menjadi sekedar konsepsi dan wacana semata, melainkan sebuah realitas objektif di Indonesia.

Melihat geliat politik Islam dari paradigma hubungan antara Islam dan negara, bukan hal baru. Paradigma yang didasarkan atas asumsi elitis ini, kurang lebih sama ketika melihat posisi media dan negara. Relasi antara Islam-NegaraMedia ini menjadi begitu penting karena dinamika ketiganya samasama punya pengaruh yang cukup besar terhadap eksistensi Indonesia saat ini. Media massa sebagai salah satu instrumen sosial masyarakat, merupakan salah satu wadah perjuangan tidak hanya oleh para aktivis Islam namun juga rangkaian ideolog, kaum intelektual dan cendekiawan Islam. Media massa telah menjadi saksi sekaligus penulis sejarah bagi pergulatan politik Islam di Indonesia.

Kajian ini memerhatikan beberapa hal. Pertama, bagaimana dan landasan filosofis apa yang dipergunakan oleh media massa dalam melihat politik Islam. Diskursus ini menjadi penting karena pekerjaan selanjutnya, kedua, adalah berusaha untuk menyelidiki apakah media menyetujui dan menolak, ataukah memberi tawaran baru terhadap persoalan politik Islam versi pemerintah, ataukah malah tidak mempunyai kebijakan tertentu mengenai pemberitaan pergulatan politik Islam dan menyerahkan sepenuhnya pada pemerintah dan masyarakat. Atau dalam kata lain, apakah media massa bersikap aktif atau pasif dalam kaitannya dengan politik Islam di Indonesia.

Adalah menarik untuk melihat bagaimanakah pola trihubungan antara negara-media massa-Islam itu: positif, negatif 
(konflik) ataukah malah ketiganya terpisahkan dan tak berhubungan sama sekali. Pertanyaan-pertanyaan, misalnya bagaimana media massa menggambarkan dinamika politik Islam dan negara, sebagai contoh, menjadi suatu hal yang menarik untuk ditelusuri. Ataukah malah terjadi hubungan mutual ataupun interdependensi atara media massapolitik Islam dan karena itu pula menjadi hubungan kontradiktif dengan negara?

Riwayat pergolakan politik di Sumatera Utara (Sumut) pun sudah cukup banyak diceritakan sebagai salah satu titik historis perjuangan bangsa. Dalam bingkai Negara Kesatuan Republik Indonesia (NKRI), adalah penting untuk melihat bagaimana situasi di Sumut yang heterogen ini dalam pergulatan politik Islam.

Media, Negara dan Masyarakat

Media adalah sebuah ruang di mana berbagai ideologi direpresentasikan, begitu kata Antonio Gramsci (Eriyanto, 2005). Di satu sisi media bisa menjadi sarana penyebaran ideologi penguasa, alat legitimasi dan kontrol atas wacana publik. Namun di sisi lain, media bisa menjadi aparat ideologi negara (ideological state apparatus). Media bukan sesuatu yang bebas, independen, tetapi memiliki keterkaitan dengan realitas sosial karena berbagai kepentingan yang bermain dalam media, termasuk kepentingan pemilik modal, sustainabilitas lapangan kerja bagi para karyawan dan sebagainya. Dalam kondisi dan posisi seperti ini, media massa tidak mungkin berdiri statis di tengah-tengah. Di antara gagasan Marxis yang begitu kompleks soal media itu, telah mendorong lahirnya teori politikekonomi, teori kritik, dan teori hegemoni media (McQuail, 1991).

Pengorganisasian media yang terikat pada kebijakan politik negara juga bervariasi. Penelitian Mary Catherine French (2014) tentang jurnalisme di Soviet kurun 19551966 , mengungkapkan pengorganisasian media resmi Liga Pemuda Komunis atau Komsomol bernama Komsomol'skaia Pravda (KP). Tiga peneliti World Bank terhadap 97 negara menyatakan, secara umum media-media besar di dunia dimiliki oleh pemerintah dan 
grup keluarga tertentu (Djankov,

2003). Penelitian UNESCO pada

1974, menyebut, telah terjadi

produksi kultural yang bersifat satu

arah (one-way flow) dari negara maju

ke negara berkembang

(Nordenstreng, 1974). Bahwa,

kendali korporasi besar terhadap

kekuasaan negara dan sebaliknya, justru menjadikan media massa hanyalah alat kekuasaan dan koorparasi, misalnya di Amerika Serikat (Rais, 2008).

Karena itu, kebebasan pers menjadi penting disinggung.

Bagaimana Indonesia memosisikan kebebasan pers? UU Pokok Pers No. 40/1999 memakai istilah kemerdekaan pers. Dalam bagian Penjelasan Pasal 4 Ayat (1) dinyatakan:

"Yang dimaksud dengan 'kemerdekaan pers dijamin sebagai hak asasi warga negara' adalah bahwa pers bebas dari tindakan pencegahan, pelarangan, dan atau penekanan agar hak masyarakat untuk memperoleh informasi terjamin. Kemerdekaan pers adalah kemerdekaan yang disertai kesadaran akan pentingnya penegakan supremasi hukum yang dilaksanakan oleh pengadilan, dan tanggung jawab profesi yang dijabarkan dalam Kode Etik Jurnalistik serta sesuai dengan hati nurani insan pers."
Namun justru di masa reformasi, perspektif kebebasan pers semakin diperluas dengan adanya persoalan di internal pers sendiri, yaitu etik pada konten informasi yang diberitakan dan "kepatuhannya" terhadap pemilik modal. Hingga 2016, media-media di Indonesia telah terkonsentrasi pada grup-grup besar pemilik modal, dengan diversifikasi usaha media yang merambah ke seluruh jenis media. Jakob Oetama (pendiri Kompas), menulis, pada era Orde Baru (orba), dengan represi kekuasaan yang intensif dan masif, media bersinggungan erat dengan masalah media dan kekuasaan, sementara masa reformasi, media dan bisnis ekonomi versus kepentingan pemilik/pemodal

(Kartosapoetro, 2014).

Politik Islam dan Media

Secara garis besar, ada dua spektrum pemikiran politik Islam yang berbeda (Effendy, 1998). Spektrum pertama beranggapan bahwa Islam harus menjadi dasar negara; bahwa syari'ah harus diterima sebagai konstitusi negara; bahwa kedaulatan politik ada di 
tangan Tuhan; bahwa gagasan tentang negara-bangsa (nation-state) bertentangan dengan konsep ummah (komunitas Islam) yang tidak mengenal batas-batas politik atau kedaerahan. Sedangkan prinsip syûrâ (musyawarah) walau diakui namun aplikasi prinsip itu berbeda dengan gagasan demokrasi politik modern dewasa ini.

Pada spektrum kedua, beberapa kalangan Muslim lainnya berpendapat bahwa Islam "tidak mengemukakan suatu pola baku tentang teori negara (atau sistem politik) yang harus dijalankan oleh ummah." Menurut aliran pemikiran ini, bahkan istilah negara (dawlah) pun tidak dapat ditemukan dalam alQur'an. Bahtiar Effendy (1998) kemudian mengajukan lima pendekatan untuk melihat hubungan antara Islam dan Politik yakni dekonfessionalisasi, domestikasi Islam, skismatik aliran, trikotomi dan Islam kultural.

Di Sumut, mobilitas keagamaan tidak bisa hanya dipahami dalam bingkai wilayah Sumut secara administratif. AlJami'atul Wasliyah (lahir pada 30 November 1930/ 9 Rajab 1349 H di
Kota Medan) yang mendominasi penyebaran di pantai Timur, mengalami persamaan dan perbedaan tipologi dengan kawasan pantai barat. Pada 1930, misalnya, Syeikh Musthafa Husain Purbabaru mendirikan Persatuan Muslim Tapanuli. Bersama muridnya, Syeikh Ahmad Dahlan, dia kemudian mendirikan Al-Ittihadiyah di Medan pada 1935 (Rasyidin, 2016).

Tidak hanya itu. Muhammadiyah yang menurut beberapa kajian sudah dimulai sejak 25 November 1927 di Kota Medan, memerlihatkan perantau pendakwah dari Minangkabau, Tapanuli Tengah, Jawa dan lain daerah turut memengaruhi kinerja organisasi. Bahkan, pada 22 Desember 1939, ketika H. R. Muhammad Said, Ketua Perwakilan Hofd Bestur (HB) Muhammadiyah Daerah Pesisir Timur, wafat, jabatannya untuk sementara digantikan, di antaranya oleh Hamka, yang berasal dari Sumatera Barat.

Memang, akan ada pertanyaan besar yang menarik. Pertama, apakah gerakan politik Islam itu bertujuan untuk memperbesar jumlah pemeluk agama 
Islam? Kedua, ataukah gerakan politik Islam bertujuan untuk menguatkan internal umat Islam saja? Dan ketiga, apakah ada kemungkinan gerakan politik Islam justru terjadi antara internal umat Islam untuk memperbesar keanggotaan dari suatu aliran atau organisasi Islam tertentu?

Di sisi lain, topik yang juga paling sering muncul saat melihat hubungan antara politik Islam dan media, adalah kata islamophobia, terorisme, radikalisme hingga fundamentalisme. Tak dapat dipungkiri kalau hancurnya World Trade Center (WTC) di New York pada 9 September 2001, menjadi semacam pemicu baru hubungan yang cenderung negatif antara media barat dengan Islam dan muslim, yang entah mengapa menular juga ke Indonesia. Kasus-kasus lain yang dinilai meruncingkan hubungan itu di antaranya Krisis Terusan Suez 1955/1956, Perang Arab-Israel 1967 dan 1973, krisis minyak 1973/1974, Revolusi Iran 1979, kasus Salman Rusdhie 1989, krisis Aljazair, dan Perang Teluk 1991 WTC (Havez, 2000). Edward Said (1997) bahkan memakai kata "trauma" dalam melihat hubungan Islam dan Barat.

\section{Metode Penelitian}

Kajian ini menggunakan pendekatan kualitatif dengan model deskriptif. Melalui pendekatan ini, diharapkan dapat secara mendalam dan komprehensif membahas, menggambarkan, mengklasifikasikan serta menarik beberapa kesimpulan untuk menjawab pertanyaanpertanyaan penelitian. Data kualitatif, seperti dikatakan Miles dan Huberman (1992), lebih condong dapat membimbing peneliti untuk memperoleh penemuan-penemuan yang tak diduga sebelumnya dan untuk membentuk kerangka teoritis baru, sehingga membantu peneliti untuk melangkah lebih jauh dari praduga dan kerangka kerja awal.

Untuk melakukan analisis dan interpretasi kualitatif maka dipakai pendekatan historiskomparatif dan pendekatan ekonomipolitik. Mula-mula penulis berharap dapat mengungkap rincian historis masalah ini dan kemudian menafsirkannya dalam kerangka teori yang digunakan dalam studi ini. Pendekatan historis komparatif ini 
karena peristiwa yang terjadi

belakangan dapat ditengarai sebagai satu rangkaian yang tak pula dapat dipisahkan begitu saja. Merangkainya dengan pendekatan ekonomi-politik dalam melihat perjalanan media massa di Indonesia, khususnya di Sumatera Utara, menjadikan kajian ini mengarah pada analisis komparatif terhadap gagasan dan praktik para pemilik dan pekerja di media massa, intelektual dan politisi muslim dari beberapa generasi yang berbeda, dan mengkomparasinya dengan kebijakan negara yang juga diambil dalam suatu masa di mana kekuatan sosial politik ekonominya juga berbeda-beda pula.

\section{Hasil dan Pembahasan}

Media Massa dan Politik Islam di Sumut

Pers Islam dapat dilihat pada tiga hal yaitu 1) Pers yang didirikan muslim ataupun kelompok Islam; 2) Pers yang diisi oleh praktisi jurnalistik muslim; dan 3) Pers yang menyuarakan kepentingan Islam.

Bila poin pertama merujuk langsung pada media massa yang khusus didirikan untuk menyuarakan
Islam, maka pada poin 2 dan 3, media massa yang dimaksud lebih bersifat umum dan ketika didirikan memang tidak dimaksudkan secara spesifik menggolongkan diri sebagai pers Islam. Karena itu, eksistensi pers Islam dimaksudkan pada dua hal yaitu sebagai objek faktual dan sebagai nilai. Dengan demikian, mengatakan pers Islam sama sekali tidak eksis, akan bertentangan dengan fakta yang telah terjadi. Dalam hal ini, maka bila pers Islam ditujukan pada bentuk eksistensi objeknya, sementara yang lain yaitu sebagai "nilai", maka dalam kajian ini dia disebut pers Islami.

Sebagai catatan pada poin ke2, walaupun media itu diisi oleh praktisi jurnalistik muslim namun belum tentu dia menyiarkan kepentingan Islam.

Kepentingan Islam ini pun mesti dikaji lebih jauh dengan menggarisbawahi apakah informasi yang disiarkan itu masuk dalam kategori positif (membela), negatif (memojokkan) atau netral. Ini dengan perhitungan bahwa penyiaran peristiwa yang berkaitan dengan Islam tanpa tendesi apa-apa (apakah negatif atau positif), juga tergambar 
dalam pemberitaan media. Artinya, informasi yang disampaikan memang hanya sekedar informasi. Ini misalnya yang terjadi ketika peristiwa-peristiwa ritual keislaman, tata cara ibadah dan lain sebagainya yang bersifat rutinitas, berseliweran di media massa, baik pers Islam, islami maupun pers umum.

Dibukanya keran kebebasan untuk menyiarkan "apa saja", sebenarnya menjadi pintu gerbang bagi aktivis dari kelompok manapun untuk menyiarkan pemikiran, kampanye, ataupun propagandanya mereka. Dan itu, termasuk bagi aktivis Islam. Dengan demikian, media pasca Reformasi 1998 pada dasarnya telah berubah menjadi lahan pertarungan ideologis bagi seluruh aliran. Tapi apakah benar para aktivis Islam memanfaatkan itu?

Untuk membahasnya, kajian ini menyinggung istilah yang umum dipakai yaitu media mainstream. Di Sumatera Utara, beberapa media yang dianggap sebagai mainstream adalah Waspada, Analisa (terbit sejak 1972, kini juga mengakuisisi harian MedanBisnis), Sinar Indonesia Baru (terbit sejak 1970).
Komposisi yang semula diikuti adalah pemilahan ketiga media besar di Sumut dalam bentuk basis sosiologis. Waspada ditandai berbasis muslim, Analisa berbasis kalangan Tionghoa Budha-HinduKonghucu dan SIB yang mengandalkan massa Kristen Protestan dan Katolik yang disebutkan beririsan dengan basis massa Huria Kristen Batak Protestan (HKBP). Namun, tipologi ini agaknya hingga kini masih sekedar asumsi umum yang belum dapat dibuktikan secara faktual. Apalagi, ada pertimbangan bahwa satu pelanggan (apakah perorangan ataupun lembaga) juga berlangganan koran yang lain.

Selain itu, bila diikuti dengan komposisi penduduk di Sumut yang sejak 1980 umat Islam sebagai mayoritas dengan persentase lebih dari 60\% (pada 1980 sebesar 61,38\% dan 2010 mencapai 66,08\%), maka dari segi segmentasi bisnis media maka komposisi ini menjadikan umat Islam sebagai pasar terbesar dari media. Karena itu, tidaklah mengherankan bila pemilahan umat Islam sebagai pasar lebih dimungkinkan dari segi profit- 
oriented daripada segi ideologis.

Karena itu, bersinggungan langsung secara negatif dengan umat Islam, akan sangat tidak menguntungkan bagi bisnis media. Ini tidak hanya berlaku bagi koran di Medan, tapi juga koran Jakarta yang beredar di Sumut, seperti Sumut Pos (Grup JawaPos) dan Tribun Medan (Grup Tribun/Kompas).

Pada era industrialisasi dan kapitalisasi media, maka hubungan media-negara-agama,

lebih

dikarenakan

kepentingan

pragmatisme sesaat, bukan hubungan yang berdasarkan kepentingan esensial dan pinsipil. Peristiwaperistiwa politik yang diberitakan, hubungan bisnis politisi-medianegara (dalam bentuk iklan maupun pemesanan pembelian surat kabar), dan lain sebagainya, terkadang hanya membuat agama menjadi sebuah jualan politik untuk mendapat, mengukuhkan, mempertahankan, hingga melanjutkan kekuasaan politik. Padahal, media sebenarnya bisa memberi tawaran baru terhadap persoalan politik Islam, paling tidak untuk meminimalisir korelasi negatif antara negara dan Islam. Apalagi, tokoh-tokoh Islam sejak sebelum
Indonesia merdeka, sebenarnya sudah mengambil jalur media untuk menyebarkan ide, pemikiran, peristiwa-peristiwa keislaman, termasuk politik.

\section{Tabel 1}

Media Terbitan Organisasi Keislaman dan Tokoh-tokoh Islam Kurun 1910-1966

\begin{tabular}{|c|c|}
\hline $\begin{array}{c}\text { ORGANISASI/ } \\
\text { TOKOH }\end{array}$ & NAMA MEDIA \\
\hline Muhammadiyah & $\begin{array}{l}\text { Soeara } \\
\text { Muhammadijah, } \\
\text { Penyiar Islam, } \\
\text { Pancaran Amal, } \\
\text { Almanak } \\
\text { Muhammadiyah, } \\
\text { Suara Aisyiyah, } \\
\text { Mertju Suar }\end{array}$ \\
\hline Persis & $\begin{array}{l}\text { Pembela Islam (1929 } \\
), \text { Al-Fatwa (1931), } \\
\text { Al-Lissan (1935), At- } \\
\text { Taqwa (1937), Al- } \\
\text { Hikam (1939), Aliran } \\
\text { Islam (1948), Risalah } \\
(1962)\end{array}$ \\
\hline $\begin{array}{l}\text { Jami'atul Al- } \\
\text { Washliyah }\end{array}$ & $\begin{array}{l}\text { Medan Islam (1933), } \\
\text { Raudhatul } \\
\text { Muta'allimin (1937), } \\
\text { Dewan Islam (1938) }\end{array}$ \\
\hline NU & $\begin{array}{l}\text { Berita NU, Duta } \\
\text { Masyarakat }\end{array}$ \\
\hline Al-Ittihadiyah & Al-Hidayah \\
\hline Syarikat Ilmu & $\begin{array}{l}\text { Al-Munir (1911- } \\
\text { 1915). Terbit di } \\
\text { Padang }\end{array}$ \\
\hline Sumatra Thawalib & $\begin{array}{l}\text { Al-Munir Al-Manar } \\
\text { (1918-1924), terbit di } \\
\text { Padang Panjang }\end{array}$ \\
\hline Sain al-Maliki & $\begin{array}{l}\text { Dunia Akhirat (1923- } \\
\text { 1925), terbit di Bukit } \\
\text { Tinggi }\end{array}$ \\
\hline
\end{tabular}




\begin{tabular}{|c|c|c|}
\hline Syekh Haji Abbas & Al-Imam & Organisasi keislaman bukan \\
\hline Padang Japang & (Payakumbuh) & tidak serius soal media, namun \\
\hline $\begin{array}{l}\text { Pelajar Islam } \\
\text { Indonesia (PII) }\end{array}$ & Islam Bergerak & cenderung tidak menjadikan \\
\hline Surabaya & Al-Jihad, Al-Islam & jurnalistik sebagai sebuah program \\
\hline $\begin{array}{l}\text { Peranakan Arab } \\
\text { Indonesia }\end{array}$ & Aliran Baru & $\begin{array}{l}\text { strategi dakwah. Lain halnya dengan } \\
\text { penyiapan kader (kaderisasi) untuk }\end{array}$ \\
\hline Abdul Wahid & Suluh Islam (Medan) & masuk ke partai-partai politik. \\
\hline KH Abdul Madjid & & Karena itu pula, bila asupan jurnalis \\
\hline Abdullah & & Islam di media-media umum yang \\
\hline HR Rasuna Said & $\begin{array}{l}\text { Menara Putri } \\
\text { (Medan) }\end{array}$ & lebih ideologis, kurang dibarengi \\
\hline $\begin{array}{l}\text { H Bakri, Bakhtiar } \\
\text { Yunus }\end{array}$ & Sinar (Medan) & $\begin{array}{l}\text { dengan pemahaman Islam yang } \\
\text { kukuh dan mendalam, melainkan }\end{array}$ \\
\hline Hamka, & $\begin{array}{l}\text { Pedoman Masyarakat } \\
\text { (Medan) }\end{array}$ & lebih umum dan bersifat sekuler \\
\hline $\begin{array}{l}\text { Mohammad Yunan } \\
\text { Nasution }\end{array}$ & & $\begin{array}{l}\text { Bahkan, darı wawancara informal } \\
\text { yang dilakukan terhadap sejumlah }\end{array}$ \\
\hline $\begin{array}{l}\text { Zainal Abidin } \\
\text { Ahmad }\end{array}$ & Panji Islam (Medan) & jurnalis muda, menyebutkan bahwa \\
\hline $\begin{array}{l}\text { KH Fakih Usman, } \\
\text { Hamka, Yusuf } \\
\text { Abdullah Puar }\end{array}$ & $\begin{array}{l}\text { Panji Masyarakat } \\
(1959)\end{array}$ & $\begin{array}{l}\text { konsepsi perjuangan Islam lewat } \\
\text { media justru adalah hal yang tidak } \\
\text { terlalu akrab alias asing. Itulah }\end{array}$ \\
\hline Mas Mansoer & Suara Santri & makanya, pergerakan politik Islam di \\
\hline Hamka & Al-Basyir & tubuh media, kurang lebih hanya \\
\hline \multirow[t]{6}{*}{$n / a$} & $\begin{array}{l}\text { 1. Sumatera Barat: } \\
\text { Medan Rakyat, } \\
\text { Matahari Islam, } \\
\text { Tafsir Quran, Al- } \\
\text { bayan, Al-Itqan }\end{array}$ & $\begin{array}{l}\text { bersifat sporadis dan tidak } \\
\text { terstruktur. }\end{array}$ \\
\hline & 2. Bandung: & Dinamika dan Output Politik Islam \\
\hline & $\begin{array}{l}\text { Pembangkit, Al- } \\
\text { Hidayah, Aliran Muda }\end{array}$ & Parpol Islam atau partai yang \\
\hline & Terbit di Bandung & berbasis dukungan umat Islam pasca \\
\hline & $\begin{array}{l}\text { 3. Samarinda: } \\
\text { Persatoean }\end{array}$ & $\begin{array}{l}1998 \text { menuju Pemilu 1999, tumbuh } \\
\text { masif sseperti seperti Partai }\end{array}$ \\
\hline & & Persatuan Pembangunan (PPP), \\
\hline $\begin{aligned} \text { Sumber } & \begin{array}{r}\text { Ruslan } \\
\text { sumber }\end{array}\end{aligned}$ & (2012) dan berbagai & $\begin{array}{l}\text { Partai Syarikat Islam Indonesia } \\
\text { (PSII), Partai Umat Islam (PUI), }\end{array}$ \\
\hline
\end{tabular}


Partai Masyumi Baru, Partai Bulan Bintang (PBB), Partai Keadilan (PK), Partai Nahdhatul Ummat (PNU), dan lain sebagainya. Itu termasuk partai yang didirikan secara langsung maupun tidak langsung oleh organisasi Islam terbesar (NU dan Muhammadiyah) yaitu Partai Kebangkitan Bangsa dan Partai Amanat Nasional. Namun, pemenang pemilu 1999 justru adalah partai beraliran nasionalis, PDI Perjuangan. Meski, Abdurrahman Wahid yang merupakan Ketua PBNU terpilih sebagai Presiden dalam pemilihan di MPR yang dipimpin oleh Amien Rais (mantan Ketua PP Muhammadiyah), juga dapat dianggap sebagai kemenangan faksi Islam.

Setelah Abdurrahman Wahid lengser, terutama di masa Megawati Soekarnoputri (2001-2004) dan Susilo Bambang Yudhoyono (20042009, 2009-2014), masyarakat Islam di Indonesia dihadapkan pada stigma "terorisme". Faktor kebijakan "war on terrorism" yang dikumandangkan AS setelah hancurnya WTC dan Pentagon, mengemuka jelas. Jangan lupa, serangkaian peledakan bom terjadi di Indonesia sebelum peristiwa ini yaitu kurun April 1999Agustus 2001 dan periode September 2001-Juli 2009. Pemerintah yang sebelumnya tidak mempunyai aturan khusus soal terorisme, mengeluarkan Perppu Nomor 1 Tahun 2002 tentang Pemberantasan Tindak Pidana Terorisme pada 18 Oktober 2002. Keluarnya Perppu itu diikuti dengan dua instruksi presiden (inpres) soal penanganan terorisme yaitu Inpres No.4 Tahun 2002 dan Inpres No.5 Tahun 2002. Perppu itu menjadi UU No. 15 Tahun 2003 tentang Tindak Pidana Kejahatan Terorisme pada 4 April 2003.

Stigma lain yang dikenakan pada Islam adalah pada kata "jihad" yang dimasukkan dalam kamar yang sama dengan kata "teror". Label itu kemudian melekat dan tersebar luas ke masyarakat, salah satunya adalah karena media yang juga meneruskan statemen-statemen resmi dari kekuasaan pasca reformasi. Karena itu pula, fungsi integratif yang diharapkan dari media, tentu saja tidak bisa diharapkan dari kelompok media sekuler yang berhasil menguasai wacana. 


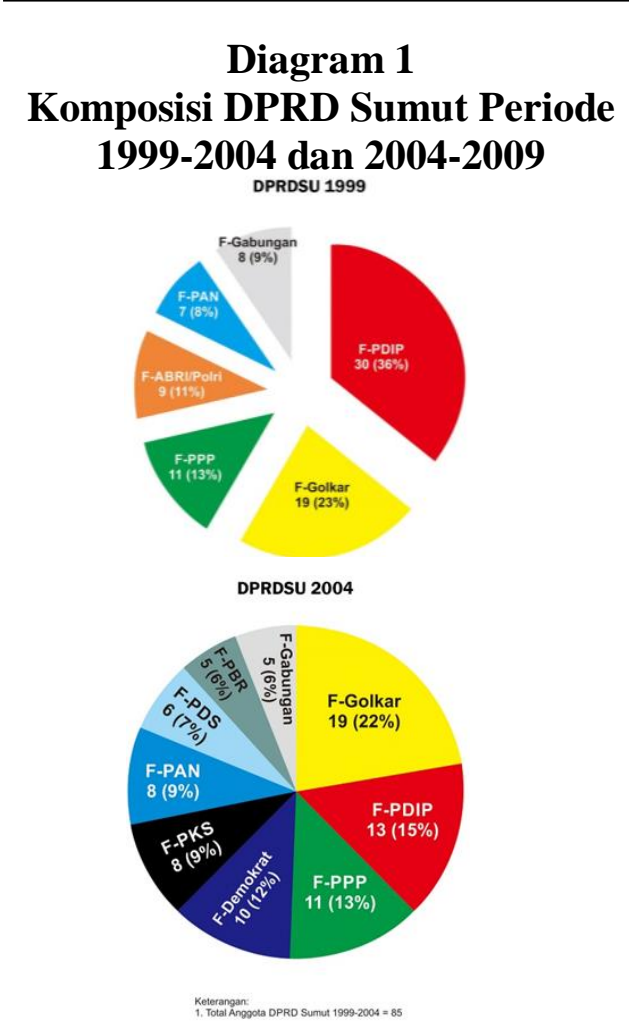

sumber: diolah dari data KPU 19992004

Data menunjukkan, pasca Pemilu 1999 ini, dinamika politik Islam (misalnya pilkada dan pemilu legislatif) di tingkat lokal juga kurang menggembirakan. Ruang parlemen telah dikuasai PDI Perjuangan dan Golkar, yang beraliran nasionalis kekaryaan. Seperti juga konstelasi di tingkat nasional, fraksi PPP berdiri sendiri, tidak bersama dengan partai yang berbasis massa tradisional Islam seperti PKB dan PAN. PKB malah bergabung dengan F-Gabungan, sementara PKS memilih bergabung dengan F-PAN.
Bandingkan pula dengan pertarungan politik kursi Dewan Perwakilan Daerah (DPD) pada Pemilu 2004, yang memerlihatkan konsolidasi organisasi Islam di Sumut. Calon bernama Abdul Halim Harahap yang merupakan pimpinan Jam'iyatul Al-Washliyah Sumut mendapatkan dukungan dari Pimpinan Wilayah Muhammadiyah Sumut dan organisasi keislaman lainnya. Konsekuensinya, Perolehan suara Abdul Halim Harahap sangat besar, 810.232 atau $16 \%$ dari total suara. Perolehan suara ini merupakan yang terbesar dalam seluruh Pemilu DPD yang berlangsung hingga kajian ini ditulis.

\section{Diagram 2 \\ Komposisi DPD Asal Sumut \\ Periode 2004-2009}

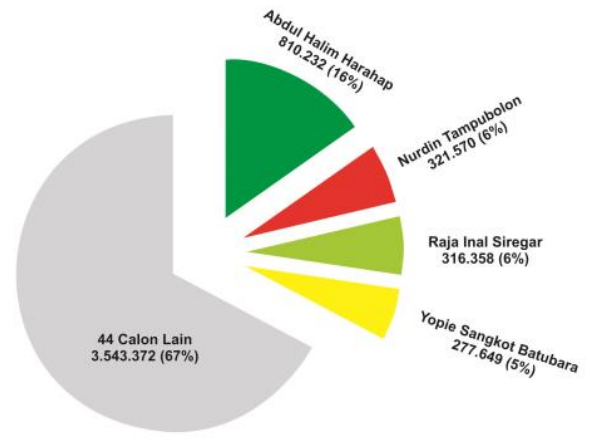

sumber: KPU Sumut 2004

Bandingkan hasil Pemilu DPD 2004 di atas, dengan komposisi DPRD Sumut periode 2004-2009 
pasca Pemilu 2004. Komposisi ini pada dasarnya memerlihatkan hal yang cukup signifikan bagi kekuatan politik Islam di Sumut, dengan berhasil menyusun hingga empat fraksi: F-PPP (13\%), F-PKS (9\%), FPBR (6\%) dan F-PAN (9\%), atau total 32 kursi $(37,6 \%)$. Di sisi lain, partai berlandaskan pemilih Kristen seperti Partai Damai Sejahtera (PDS), juga mampu meraih hasil signifikan dan berhasil membentuk satu fraksi. Sementara itu, dari 29 anggota DPR asal Sumut, PPP, PKS, PAN dan PBR mampu mengirim 11 utusan.

Namun, konsolidasi pada Pemilu 2004 itu, tidak terlihat di Pemilu 2009. Calon non-muslim berhasil meletakkan dua calonnya (bahkan meraih suara terbanyak 1 dan 2) sebagai anggota terpilih DPD 2009-2014 (Rudolf M. Pardede dan Parlindungan Purba), setelah sebelumnya hanya berhasil mengirim Nurdin M. Tampubolon ke Jakarta. Hal ini menguatkan argumentasi bahwa kelompok non-muslim lebih solid dalam mengkonsolidasikan kekuatan dan kepentingannya.

Komposisi DPRD Sumut periode 2009-2014 juga tidak memerlihatkan dominasi kekuatan politik Islam. Pertambahan kursi hanya diperoleh PKS, sementara PPP, PBR dan PAN menurun. Di sisi lain, di samping PDS ada pula FPPRN (Partai Peduli Rakyat Nasional) yang diisi oleh mayoritas non-muslim. Di lain pihak, hanya PPP, PKS dan PAN saja yang bisa mengirimkan wakilnya menjadi anggota DPR RI asal Sumut periode 2009-2014.

Uraian di atas, dapat diinterpretasikan bahwa solidaritas dan soliditas dalam menjembatani kepentingan untuk masuk dalam ranah kekuasaan, tidak mengalami konsistensi yang kukuh dan bersifat temporer (sementara). Ketiadaan kinerja yang terstruktur, sistematis dan stabil/konstan antara berbagai kekuatan politik umat Islam, seperti yang telah disinggung sebelumnya, mendapatkan argumentasinya di sini.

Karena itu pula, reformasi 1998 yang membuka keran bagi kencangnya aktivis Islam dalam politik praktis, ternyata tidak membuat banyak keuntungan bagi kepentingan umat Islam secara keseluruhan, apalagi bila dikaitkan dengan revivalisme (kebangkitan) 
Islam. Masuknya aktivis Islam dalam struktur partai yang non-Islam, justru dinilai malah tidak akan mampu untuk berbuat banyak bagi kepentingan Islam. Hal tersebut tentu saja berpengaruh pada output parlemen yaitu budgetting, pengawasan, dan legislasi, yang pada kenyataannya tidak terlalu menggembirakan bagi kepentingan Islam. Meskipun, gerakan politik Islam memang tidak bisa direduksi pada aktivitas politik praktis di dataran parlemen.

Ketidaksolidan kekuatan politik Islam ini berbanding terbalik dengan progres kekuatan politik dan agregasi kepentingan kelompok nonmuslim pasca 1998. Di antara contoh yang dapat dikemukan adalah pertambahan jumlah rumah ibadah di Indonesia khususnya di Sumatera Utara.

Tabel 2

Pertumbuhan Rumah Ibadah di Sumatera Utara Periode 1998-2010

\begin{tabular}{cccccc}
\hline \multicolumn{5}{c}{ GEREJA } \\
TAH & MASJ & PROT & KAT & KU & VIH \\
UN & ID & ESTA & OLI & IL & ARA \\
& & N & K & & \\
1998 & 8.685 & 9.404 & 1.684 & 42 & 153 \\
1999 & 8.688 & 9.404 & 1.693 & 47 & 153 \\
2000 & 8.049 & 8.522 & 1.752 & 118 & 310 \\
2001 & 7.822 & 10.148 & 2.061 & 50 & 505 \\
2002 & - & - & - & - & - \\
2003 & 7.319 & 9.912 & 2.064 & 215 & 247 \\
\hline
\end{tabular}

\begin{tabular}{cccccc}
\hline 2004 & - & - & - & - & - \\
2005 & 8.328 & 9.812 & 2.055 & 52 & 157 \\
2006 & 9.199 & 9.812 & 2.092 & 58 & 206 \\
2007 & 9.199 & 10.277 & 2.134 & 367 & 77 \\
2008 & 9.201 & 10.148 & 2.098 & 72 & 367 \\
2009 & 9.290 & 11.989 & 2.164 & 65 & 367 \\
2010 & 9.011 & 9.514 & 1.814 & 710 & 1.234 \\
\hline
\end{tabular}

sumber: diolah dari data BPS Sumut 1998-2010

Data di atas menunjukkan jumlah rumah ibadah umat Islam lebih sedikit daripada umat nonmuslim, terutama Kristen Protestan. Angka itu akan jauh lebih sedikit bila rumah ibadah Kristen Protestan dan Katolik digabungkan. Data ini akan lebih menarik ketika jumlah pemeluk agama di Sumut dibandingkan dengan jumlah rumah ibadahnya. Mari ambil perbandingan di tahun 2010.

Tabel 2

Rasio Pemeluk Agama dan Rumah Ibadah di Sumut 2010

\begin{tabular}{|c|c|c|c|c|}
\hline AGAMA & \multicolumn{2}{|c|}{$\begin{array}{c}\text { RUMAH } \\
\text { IBADAH } \\
2010\end{array}$} & \multirow{2}{*}{$\begin{array}{c}\text { PEME } \\
\text { LUK } \\
\text { 2010 } \\
8.579 .8 \\
30\end{array}$} & \multirow{2}{*}{$\begin{array}{c}\text { RAS } \\
\text { IO } \\
1: \\
952\end{array}$} \\
\hline ISLAM & $\begin{array}{c}\text { Masji } \\
\mathrm{d}\end{array}$ & $\begin{array}{c}9.0 \\
11\end{array}$ & & \\
\hline $\begin{array}{l}\text { PROTES } \\
\text { TAN }\end{array}$ & Gereja & $\begin{array}{l}9.5 \\
14\end{array}$ & $\begin{array}{c}3.509 .7 \\
00\end{array}$ & $\begin{array}{c}1: \\
368\end{array}$ \\
\hline $\begin{array}{l}\text { KATOLI } \\
\mathrm{K}\end{array}$ & Gereja & $\begin{array}{l}1.8 \\
14\end{array}$ & 516.037 & $\begin{array}{c}1: \\
284\end{array}$ \\
\hline HINDU & Pura & 710 & 14.644 & 1: 20 \\
\hline BUDHA & Vihara & $\begin{array}{l}1.2 \\
34\end{array}$ & 303.548 & $\begin{array}{c}1: \\
245\end{array}$ \\
\hline $\begin{array}{l}\text { KONGH } \\
\text { UCU }\end{array}$ & $\begin{array}{l}\text { Kelent } \\
\text { eng }\end{array}$ & 65 & 984 & 1: 15 \\
\hline $\begin{array}{l}\text { sumber: } \\
2010\end{array}$ & lah & & BPS & umut \\
\hline
\end{tabular}


Sibolga, Humbang Hasundutan,

Dalam data itu tergambar jelas bila di 2010, umat Islam di Sumut yang jumlahnya mayoritas $(66,08 \%)$ mengalami rasio yang terendah: sebuah masjid rata-rata harus melayani 952 umat Islam (1:952). Rasio itu sangat jauh bila dibandingkan dengan umat Kristen Katolik dan Protestan, dan terutama dengan agama baru, Konghucu. Bandingkan pula hasil ini dengan rasio rata-rata nasional untuk umat Islam yang 1:322, maka perbandingannya sangat jauh. Lihat pula rasio umat non-muslim, misalnya Kristen Protestan dan Katolik, yang tidak berbeda jauh dengan rasio rata-rata nasional. Dari sisi ini, maka pekerjaan rumah bagi kekuatan politik Islam di Sumut, nyatanya jauh lebih besar dari ratarata nasional.

Memang, untuk menarik sebuah interpretasi dari data-data di atas, maka harus diperhitungkan pula nilai rata-rata persebaran di seluruh kawasan. Faktanya, di Sumut sendiri memang terbagi pada kawasan yang mayoritas muslim dan non-muslim terutama Kristen di kawasan Tapanuli Utara, Tapanuli Tengah,
Simalungun, Siantar hingga Nias.

Namun, dengan mengambil persentase mayoritas muslim di Sumut, maka nilai itu, sekali lagi, mengisyaratkan bahwa output kekuatan politik umat Islam di Sumut masih perlu banyak pertanyaan.

Belum lagi bila penelitian ini menyelidiki lebih jauh data-data alokasi anggaran APBD Sumut dan Kabupaten/Kota terhadap organisasi Islam, organisasi kemahasiswaan Islam, lembaga-lembaga pendidikan, perayaan hari besar Islam, dan lainlain yang berkaitan dengan kepentingan umat Islam, misalnya saja perda syariah.

Karena itu, di hadapan serbuan wacana dan informasi yang tidak memihak kepada Islam secara langsung maupun tidak langsung, pilihan untuk mempunyai media massa sendiri dirasakan sebagai hal yang realistis. Namun, bukan berarti tidak mempunyai kendala. Seperti yang sudah diurai dalam bagian sebelumnya, kendala manajemen dan profesionalisme praktisi pers, masih menghadang. Selain itu, faktor kapabilitas sumber daya jurnalis 
Islam dalam mengendus dan menghadapi isu-isu keislaman juga duduk dalam daftar masalah yang harus diselesaikan. Majalah-majalah Islam juga sudah lama tutup di antaranya Panji Masyarakat, Amanah, Media Dakwah, Al Muslimun, Ummat hingga Madina. Karena itu, jalur dakwah yang dipakai selama ini yaitu dakwah dari mimbar ke mimbar, akan terlihat konvensional bila dibandingkan dengan massifnya perkembangan media massa dan new wave media. Tema-tema yang diberikan dalam model komunikasi langsung tatap muka seperti itu, menghadapi kendala yang bersifat konvensional seperti persebaran dan tak tersimpan dalam waktu yang panjang (short term). Pada dasarnya, dakwah literasi dan multimedia, yang sangat bisa diakomodir dan bahkan menjadi pekerjaan rutin dari media massa, belum dimanfaatkan secara maksimal untuk kepentingan politik Islam. Lagipula, adanya keengganan untuk membahas tema-tema politik Islam dalam pengajian-pengajian komunitas hingga masjid-masjid, kian melemahkan pandangan umat
Islam terhadap kondisi riil sosial politik yang dihadapi di Sumut.

Dengan realitas politik yang begitu kecil kemungkinannya, maka seperti sudah dikatakan sebelumnya, pertarungan yang tersisa bagi Politik Islam adalah mengisi struktur kekuasaan, baik di eksekutif maupun legislatif.

\section{Penutup}

Diskursus politik Islam di media pasca reformasi, tak terpisahkan dengan depolitisasi politik Islam di masa orba yang kemudian menentukan wacana keislaman di Sumut dan turut menyumbang melemahnya potensi kekuatan politik Islam. Definisi dan pemaknaan politik Islam di kalangan media maupun aktivis sosial politik Islam di Sumut, secara garis besar terbelah pada pemahaman holistik (radikal maupun moderat) dan sekuler.

Ketiadaan media yang berkonsentrasi pada politik Islam, dan lebih memilih segmentasi umum-sekuler, membuat agenda politik Islam tergantung pada pertimbangan ideologis pemilik dan pilihan segmentasi pasar. Selain itu, 
program khusus terstruktur dan sistematis yang berkonsentrasi di bidang jurnalisme Islam di organisasi dan partai keislaman, sangat minim, sporadis, tak terjadwal, dan tidak mempunyai output tertentu soal media dan politik Islam. Sehingga, media umum yang lebih sekuler menguasai penyebaran wacana dan informasi.

\section{Daftar Pustaka}

Badan Pusat Statistik. 2010. Kewarganegaraan, Suku Bangsa, Agama dan Bahasa Sehari-hari Penduduk Indonesia: Hasil Sensus Penduduk 2010. Jakarta: Badan Pusat Statisik

Badan Pusat Statistik Provinsi Sumatera Utara. 2001-2013. Sumatera Utara dalam Angka. Medan: Badan Pusat Statistik Provinsi Sumatera Utara.

Djankov, Simeon, et. al. 2003. "Who Owns the Media?" dalam Journal of Law and Economics vol. XLVI (October 2003), University of Chicago. (sumber: https://scholar.harvard.edu/files/ shleifer/files/media.pdf), diakses 10 September 2016.

Effendy, Bahtiar. 1998. Islam dan Negara: Transformasi Gagasan dan Praktik Politik Islam di Indonesia. Jakarta: Paramadina.

Eriyanto. 2005. Analisis Wacana, Pengantar Analisis Teks Media. Yogyakarta: LkiS.
French, Mary Catherine. 2014. "Reporting Socialism: Soviet Journalism and the Journalists' Union, 1955-1966,". Publicly Accessible Penn Dissertations, Pennsylvania: Penn Libraries University Pennsylvania. (http://repository.upenn.edu/cgi/ viewcontent.cgi? article $=3089 \& \mathrm{c}$ ontext=edissertations), pada 3 September 2016.

Hafez, Kai. 2000. "The West and Islam in the Mass Media: Cornerstones for a New International Culture of Communication in the 21st Century,". Makalah, Zentrum fur Europaische Integrationforschung Discussion Paper $\quad$ C 61. (http://aei.pitt.edu/181/) diakses 7 September 2016.

Haryanto, Ignatius. 2011. "Media Ownership and Its Implication for Journalists and Journalism in Indonesia," dalam Krishna Sen and David Hill (eds.), Politics and the New Media in 21st Century Indonesia: Decade of Democracy. New York: Routledge,.

Kartosapoetro, Ishadi Soetopo. 2014. Media dan Kekuasaan: Televisi di Hari-hari Terakhir Presiden Soeharto. Jakarta: Penerbit Buku Kompas.

Lim, Merlyna. 2012. The League of Thirteen: Media Concentration in Indonesia. Arizona: Participatory Media Lab Arizona State University. (http://www.public.asu.edu/ mli 
m4/files/Lim_IndoMediaOwners hip_2012.pdf), diakses 10 Maret 2013.

Manan, Abdul. 2010. Ancaman itu Datang dari Dalam: Laporan Tahunan Aliansi Jurnalis Independen 2010. Jakarta: Aliansi Jurnalis Independen.

McQuail, Denis. 1991. Teori Komunikasi Massa, Suatu Pengantar. Edisi Kedua. Jakarta: Erlangga.

Miles, Matthew B. dan A. Michael Huberman. (1992). Analisis Data Kualitatif: Buku Sumber Tentang Metode-metode Baru. Jakarta: UI Press.

Rais, Mohammad Amien. 2008. Agenda Mendesak Bangsa, Selamatkan Indonesia!. Yogyakarta: PPSK Press.

Rasyidin, Al. 2016. "Islamic Organizations in North Sumatra; The Politics of Initial Establishment and Later Development," dalam Journal of Indonesia Islam Vol 10 No. 1 Juni 2016. (http://jiis.uinsby.ac.id/index.php /JIIs/article/view /210/164), diakses 30 Oktober 2016.

Republika. 2012. "Pertumbuhan Masjid di Indonesia Rendah,". Ahad, 3 Juni 2012. (http://www.republika.co.id/berit a/dunia-islam/islamnusantara/12/06/03/m51lw4pertumbuhan-masjid-diindonesia-rendah), diakses 22 Oktober 2016.
Ruslan, Heri. 2012. "Hikayat Media Massa Islam di Nusantara,". Selasa $10 \quad$ April 2012. (https://www.republika.co.id/ber ita/duniaislam/khazanah/12/04/10/m297o 9-hikayat-media-massa-islamdi-nusantara), diakses 20 September 2016.

Said, Edward. 1997. Covering Islam. Vintage: London. 